\title{
Litorimonas taeanensis gen. nov., sp. nov., isolated from a sandy beach
}

\author{
Ji Young Jung, ${ }^{1}$ Jeong Myeong Kim, ${ }^{1}$ Hyun Mi Jin, ${ }^{1}$ Sun Young Kim, ${ }^{2}$ \\ Woojun Park ${ }^{3}$ and Che Ok Jeon ${ }^{1}$ \\ ${ }^{1}$ Department of Life Science, Chung-Ang University, Seoul 156-756, Republic of Korea \\ ${ }^{2}$ Environmental Biotechnology National Core Research Center, Gyeongsang National University, \\ Jinju 660-701, Republic of Korea \\ ${ }^{3}$ Division of Environmental Science and Ecological Engineering, Korea University, Seoul 136-701, \\ Republic of Korea
}

Correspondence

Che Ok Jeon

cojeon@cau.ac.kr

\begin{abstract}
A heterotrophic, Gram-negative, prosthecate bacterium, designated strain $\mathrm{G}^{\top}{ }^{\top}$, was isolated from a sandy beach of Taean in South Korea. Cells of strain $\mathrm{G} 5^{\top}$ were aerobic, catalase- and oxidasepositive, straight to slightly curved motile rods with a single flagellum and formed yellow-orange colonies on agar. Growth occurred at $15-40{ }^{\circ} \mathrm{C}$ (optimum $25-30{ }^{\circ} \mathrm{C}$ ) and $\mathrm{pH} 6-9$ (optimum $\mathrm{pH} 7-8)$. The major cellular fatty acids were $\mathrm{C}_{18: 1} \omega 7 c, \mathrm{C}_{17: 0}, \mathrm{C}_{16: 0}, 11$-methyl $\mathrm{C}_{18: 1} \omega 7 c$, $\mathrm{C}_{17: 1} \omega 8 \mathrm{c}$ and $\mathrm{C}_{17: 1} \omega 6 \mathrm{c}$. The polar lipid pattern indicated the presence of phosphatidylglycerol, monoglycosyldiglyceride, glucuronopyranosyldiglyceride and two unidentified glycolipids.

The $\mathrm{G}+\mathrm{C}$ content of the genomic DNA was $63.6 \mathrm{~mol} \%$ and the major quinone was Q-10. Comparative 16S rRNA gene sequence analysis showed that strain $\mathrm{G}^{\top}{ }^{\top}$ belonged to the branch containing the genera Hellea, Robiginitomaculum and Hypomonas within the family

Hyphomonadaceae. Within this group, strain $\mathrm{G}^{\top}{ }^{\top}$ was most closely related to Hellea balneolensis 26III/A02/215 ${ }^{\top}$ with $95.8 \% 16 \mathrm{~S}$ rRNA gene sequence similarity. Based on its phylogenetic position and its phenotypic, chemotaxonomic and molecular properties, strain $\mathrm{G}^{\top}{ }^{\top}$ represents a novel species of a novel genus of the family Hyphomonadaceae, for which the name Litorimonas taeanensis gen. nov., sp. nov. is proposed. The type strain is $\mathrm{G5}^{\top}\left(=\mathrm{KACC} 13701^{\top}=\mathrm{DSM} 22008^{\top}\right)$.
\end{abstract}

In 2005 the genera Hyphomonas, Hirschia, Maricaulis and Oceanicaulis were combined into a new family, Hyphomonadaceae Lee et al. (2005), in the order Rhodobacterales of the class Alphaproteobacteria based on phylogenetic analysis of $16 \mathrm{~S}$ rRNA gene sequences. Since then, new members of the family Hyphomonadaceae have been isolated from marine environments, such as the genera Robiginitomaculum (Lee et al., 2007), Hellea (Alain et al., 2008) and Maribaculum (Lai et al., 2009). Some members of the family Hyphomonadaceae possess one or more stalks called prosthecae (Abraham et al., 1999; Weiner et al., 2000; Strömpl et al., 2003; Alain et al., 2008), which are cytoplasmic extrusions that undoubtedly play a role in attachment. During the course of an investigation into the bacterial communities present in the seashore of the Yellow

Abbreviations: GUDG, glucuronopyranosyldiglyceride; MGDG, monoglycosyldiglyceride; ML, maximum-likelihood; MP, maximum-parsimony; $\mathrm{NJ}$, neighbour-joining; PG, phosphatidylglycerol.

The GenBank/EMBL/DDBJ accession number for the 16S rRNA gene sequence of strain $G 5^{\top}$ is FJ230838.

One supplementary table is available with the online version of this paper.
Sea in Korea (Kim et al., 2010), a novel Gram-reactionnegative bacterium bearing a stalk and belonging to the family Hyphomonadaceae was isolated. Here, we describe the taxonomic characterization of a novel species of a novel genus, Litorimonas, within the family Hyphomonadaceae.

Strain $\mathrm{G5}^{\mathrm{T}}$ was isolated from sand-soil of a beach of the Yellow Sea in Taean, South Korea using previously described procedures with some modifications (Kim et al., 2008). Briefly, a sand-soil sample was serially diluted in marine broth (MB; Difco), spread on Marine agar 2216 (MA; Difco) and incubated at $25^{\circ} \mathrm{C}$ for 5 days. Genomic DNA from selected colonies was prepared and PCR amplification of $16 \mathrm{~S}$ rRNA genes was performed as described previously (Lu et al., 2006). The amplicons were double-digested with HaeIII and HhaI, their fragment patterns were analysed on $2.5 \%$ MetaPhore agarose (BioWhittaker) gels and PCR products containing distinct fragment patterns were sequenced. The resulting $16 \mathrm{~S}$ rRNA gene sequences were analysed using the BLAST program (http://blast.ncbi.nlm.nih.gov/Blast.cgi) in GenBank. From the analysis, a novel strain belonging to the family Hyphomonadaceae, designated strain $\mathrm{G5}^{\mathrm{T}}$, was selected to undergo further phenotypic and phylogenetic analysis. The novel strain was grown routinely on MA at 


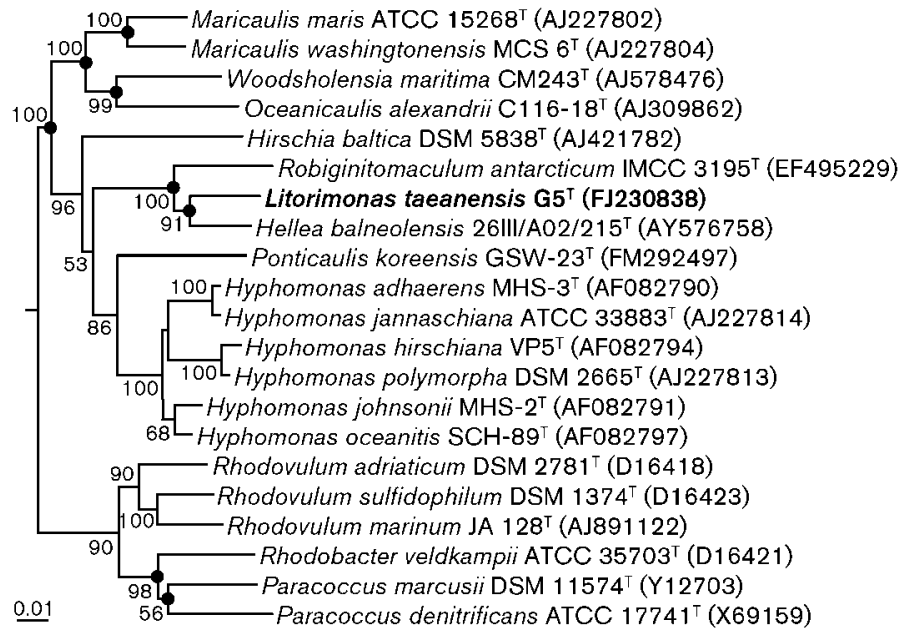

Fig. 1. Neighbour-joining tree based on $16 \mathrm{~S}$ rRNA gene sequences showing the phylogenetic relationships between strain $\mathrm{G}^{\top}$ and related taxa. Bootstrap values $>50 \%$ (based on 1000 replicates) are shown at branch points. Filled circles indicate nodes that were also recovered in trees generated using the $\mathrm{MP}$ and $\mathrm{ML}$ algorithms. Escherichia coli ATCC $11775^{\top}$ (X80725) was used as an outgroup (not shown). Bar, 0.01 substitutions per nucleotide position.
$30{ }^{\circ} \mathrm{C}$ for 3 days under aerobic conditions, except where indicated otherwise, and was stored at $-80{ }^{\circ} \mathrm{C}$ in $\mathrm{MB}$ supplemented with $10 \%(\mathrm{v} / \mathrm{v})$ glycerol for preservation. Hellea balneolensis DSM $19091^{\mathrm{T}}$ and Hyphomonas polymorpha DSM $2665^{\mathrm{T}}$, purchased from DSMZ (Germany), and Robiginitomaculum antarcticum KCCM $42687^{\mathrm{T}}$, purchased from KCCM (South Korea), were used as reference strains for phenotypic characterization and fatty acid analysis.

The 16S rRNA gene sequence (1357 nt) of strain $G 5^{\mathrm{T}}$ was compared with available 16S rRNA gene sequences from GenBank using the BLAST program. Sequence similarity values between the isolate and related taxa were evaluated using the EzTaxon nucleotide similarity search program (http://147.47. 212.35:8080/; Chun et al., 2007) and aligned by using the CLUSTAL W software program (Thompson et al., 1994). Phylogenetic trees were constructed by using the neighbourjoining (NJ), maximum-likelihood (ML) and maximumparsimony (MP) algorithms available in PHYLIP software version 3.6 (Felsenstein, 2002). The resulting tree topology constructed by the NJ method was evaluated using bootstrap analysis based on 1000 resampled datasets in the PHYLIP software package. Comparative analysis of the 16S rRNA gene sequences showed that strain $\mathrm{G} 5^{\mathrm{T}}$ was most closely related to H. balneolensis $26 \mathrm{III} / \mathrm{A} 02 / 215^{\mathrm{T}}$ and Robiginitomaculum antarcticum IMCC $3195^{\mathrm{T}}$ with sequence similarities of 95.8 and $94.3 \%$, respectively. $16 \mathrm{~S}$ rRNA gene sequence similarities with the other related type species were $<92.3 \%$. Phylogenetic analysis based on 16S rRNA gene sequences indicated that strain $\mathrm{G} 5^{\mathrm{T}}$ formed a phyletic lineage with $H$. balneolensis 26III/A02/215 ${ }^{\mathrm{T}}$ within the family Hyphomonadaceae with $91 \%$ bootstrap support. (Fig. 1). Analysis with the ML and MP algorithms also showed that the strain formed a phyletic clade with $H$. balneolensis $26 \mathrm{III} / \mathrm{A} 02 / 215^{\mathrm{T}}$ (Fig. 1).

Growth of strain $\mathrm{G} 5^{\mathrm{T}}$ at different temperatures and $\mathrm{pH}$ levels was determined by growing the isolate on MA at $5-45{ }^{\circ} \mathrm{C}$ with intervals of $5{ }^{\circ} \mathrm{C}$ and in marine broth (MB) adjusted to $\mathrm{pH}$ 5-10 with intervals of $0.5 \mathrm{pH}$ units. $\mathrm{pH}$ was adjusted prior to sterilization by the addition of $\mathrm{HCl}$ or $\mathrm{NaOH}$ and measured again after sterilization. Gram staining was performed using a bioMérieux Gram Stain kit according to the manufacturer's instructions. Cell morphology and the presence of flagella were determined using phase-contrast microscopy and transmission electron microscopy (JEM1010, JEOL) using two-day-old cells grown in $\mathrm{MB}$ as described previously (Jeon et al., 2004). Requirement and tolerance of $\mathrm{NaCl}$ were determined using nutrient broth (containing $3 \mathrm{~g}$ beef extract $\mathrm{l}^{-1}$ and $5 \mathrm{~g}$ peptone $\mathrm{l}^{-1}$ ) supplemented with modified artificial seawater (ASW) comprising $\left(\mathrm{l}^{-1}\right) \quad 0-10 \%(\mathrm{w} / \mathrm{v}) \mathrm{NaCl}$ at $0.5 \%$ intervals, $5.94 \mathrm{~g} \mathrm{MgSO}_{4} .7 \mathrm{H}_{2} \mathrm{O}, 4.53 \mathrm{~g} \mathrm{MgCl}_{2} \cdot 6 \mathrm{H}_{2} \mathrm{O}, 0.64 \mathrm{~g} \mathrm{KCl}$ and $1.3 \mathrm{~g} \mathrm{CaCl}_{2}$ (Kahng et al., 2009). Oxidase activity was tested by oxidation of $1 \%(\mathrm{w} / \mathrm{v})$ tetramethyl-p-phenylenediamine (Merck) and catalase activity was evaluated by the production of oxygen bubbles in $3 \%(\mathrm{v} / \mathrm{v})$ hydrogen peroxide solution (Smibert \& Krieg, 1994). Nitrate reduction was assessed according to the method of Lanyi (1987). Antibiotic susceptibility tests were performed in duplicate using filterpaper discs ( $8 \mathrm{~mm}$ diameter) containing the following antibiotics ( $\mu \mathrm{g}$ per disc unless stated otherwise): ampicillin (10), polymyxin B (100 U), streptomycin (50), penicillin G

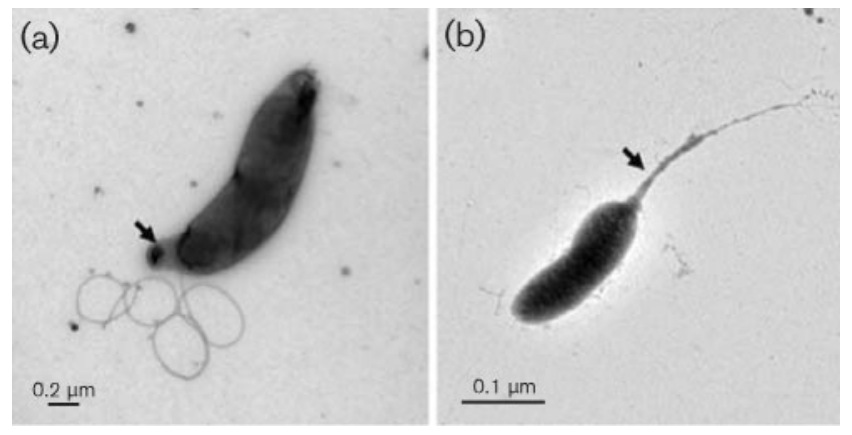

Fig. 2. Transmission electron micrographs of strain $\mathrm{G}^{\top}{ }^{\top}$ negatively stained with uranyl acetate after growth for 3 days at $30^{\circ} \mathrm{C}$ in $\mathrm{MB}$. (a) Curved rod showing budding (arrow). (b) Cell possessing a thin prostheca (arrow). Bars: $0.2 \mu \mathrm{m}$ (a), $1 \mu \mathrm{m}$ (b). 
(10 IU), gentamicin (30), chloramphenicol (100), tetracycline (30), kanamycin (30), lincomycin (15), oleandomycin (15), carbenicillin (100) and novobiocin (50). Additional phenotypic properties of strain $\mathrm{G}^{\mathrm{T}}$ and the reference strains were determined using API ZYM and API 20 NE kits (bioMérieux) and the GN2 MicroPlate system (Biolog) according to the manufacturers' instructions. The test strips were incubated at $30{ }^{\circ} \mathrm{C}$ for 3 days except for $R$. antarcticum KCCM $42687^{\mathrm{T}}$ $\left(20{ }^{\circ} \mathrm{C}\right)$ and all suspension media were supplemented with ASW containing $2 \%(\mathrm{w} / \mathrm{v}) \mathrm{NaCl}$. Growth was assessed under aerobic conditions (4-10\% $\mathrm{CO}_{2}$ ) on MA by using the GasPak Plus system (BBL) at $30{ }^{\circ} \mathrm{C}$ for 20 days.

Growth of strain $\mathrm{G} 5^{\mathrm{T}}$ occurred at $15-40{ }^{\circ} \mathrm{C}$ (optimum $25-$ $30{ }^{\circ} \mathrm{C}$ ) and $\mathrm{pH}$ 6-9 (optimum of $\mathrm{pH} 7-8$ ). Cells were Gramreaction-negative and were straight to curved motile rods bearing a prostheca $(0.4-0.6 \times 1.6-2.0 \mu \mathrm{m})$ and a single polar flagellum when grown at $30{ }^{\circ} \mathrm{C}$ on MA (Fig. 2). Details of the phenotypic characteristics of strain $\mathrm{G}^{\mathrm{T}}$ and those of closely related taxa are given in the genus and species descriptions and in Table 1. Some of phenotypic features clearly differentiated strain $\mathrm{G} 5^{\mathrm{T}}$ from closely related type strains of members the family Hypomonadaceae. Isoprenoid quinones were analysed using HPLC (model LC-20A, Shimadzu) equipped with a diode array detector (SPD-M20A, Shimadzu) and a reversedphase column $(250 \times 4.6 \mathrm{~mm}$, Kromasil, Akzo Nobel) as described previously (Komagata \& Suzuki, 1987). For fatty acid methyl ester analysis, cells of strain $\mathrm{G} 5^{\mathrm{T}}$ and reference strains were harvested after incubation at $30{ }^{\circ} \mathrm{C}$ for 3 days on MA except for $R$. antarcticum KCCM $42687^{\mathrm{T}}$, which was cultivated on MA at $20{ }^{\circ} \mathrm{C}$. Analysis of fatty acid methyl esters was performed according to the instructions of the Microbial Identification System (MIDI).

Polar lipids were determined by TLC as described by Minnikin et al. (1977). The DNA G +C content of strain $\mathrm{G}^{\mathrm{T}}$ was determined using HPLC fitted with a reversedphase column (GROM-SIL 100 ODS-2FE, GROM) according to the method of Tamaoka \& Komagata (1984). The major respiratory quinone of strain $\mathrm{G} 5^{\mathrm{T}}$ was ubiquinone- 10 (Q-10). The major cellular fatty acids $(>5 \%$ of the total fatty acids) were $\mathrm{C}_{18: 1} \omega 7 c(26.9 \%), \mathrm{C}_{17: 0}(18.5 \%), \mathrm{C}_{16: 0}$ $(17.7 \%), 11$-methyl $\mathrm{C}_{18: 1} \omega 7 c(7.9 \%), \mathrm{C}_{17: 1} \omega 8 c(6.8 \%)$ and $\mathrm{C}_{17: 1} \omega 6 c(6.5 \%)$ (Table 2$)$. Although the overall fatty acid

Table 1. Differential phenotypic characteristics of strain $G 5^{\top}$ and closely related phylogenetic neighbours of the family Hyphomonadaceae

Taxa: 1, strain G5 ${ }^{\mathrm{T}}$ (results from this study); 2, Hellea balneolensis DSM 19091 ${ }^{\mathrm{T}}$ (Alain et al., 2008); 3, Robiginitomaculum antarcticum KCCM $42687^{\mathrm{T}}$ (Lee et al., 2007); 4. Hyphomonas polymorpha DSM 2665 ${ }^{\mathrm{T}}$ (Weiner et al., 1985; Kang and Lee 2009; Abraham et al., 1999). All strains were positive for the following characteristics: alkaline phosphatase, esterase, lipase (C8), leucine arylamidase, valine arylamidase and naphthol-AS-B1phosphohydrolase activities (API ZYM). +, Positive; -, negative; (+), weakly positive; ND, no data available; tr, trace amount (<1\%); Tau, 1,2diacyl-3- $\alpha$-D-glucuropyranosyl-sn-glycerol taurineamide; PL, unidentified phospholipid; GL, unidentified glycolipid.

\begin{tabular}{|c|c|c|c|c|}
\hline Characteristics & 1 & 2 & 3 & 4 \\
\hline Shape & Straight or curved rod & Rod or vibrioid & Rod or vibrioid & Spheroid \\
\hline Pigmentation & Yellow-orange & Black-red & Rusty orange & Grey or colourless \\
\hline Flagella & + & + & - & + \\
\hline Budding & + & + & - & + \\
\hline Oxidase & + & + & - & + \\
\hline Growth at $6 \%(\mathrm{w} / \mathrm{v}) \mathrm{NaCl}$ & $(+)$ & - & - & - \\
\hline Optimum growth temperature $\left({ }^{\circ} \mathrm{C}\right)$ & $25-30$ & 30 & 20 & $30-37$ \\
\hline \multicolumn{5}{|l|}{ Enzyme activities (API ZYM)* } \\
\hline Lipase (C14) & - & $(+)$ & + & - \\
\hline Crystine arylamidase & + & - & + & + \\
\hline Acid phosphatase & + & + & - & + \\
\hline Trypsin & + & $(+)$ & - & + \\
\hline$\alpha$-Chymotrypsin & + & $(+)$ & - & + \\
\hline \multicolumn{5}{|l|}{ Utilization of $\left(\right.$ Biolog GN2) ${ }^{\star}$ : } \\
\hline Tween 40 & + & - & + & - \\
\hline D-Fructose & - & - & + & - \\
\hline D-Glucose & - & + & + & - \\
\hline Raffinose & - & - & + & + \\
\hline Polar lipids & $\begin{array}{l}\text { PG, GL1, GL2, } \\
\text { MGDG, GUDG }\end{array}$ & $\begin{array}{c}\text { PG, GL, MGDG, } \\
\text { GUDG, } \mathrm{PL}_{1}, \mathrm{PL}_{2}, \mathrm{PL}_{3}\end{array}$ & ND & $\begin{array}{c}\text { MGDG, GUDG, } \\
\text { PG, Tau }\end{array}$ \\
\hline Major quinone & Q-10 & Q-10 & Q-10 & Q-10/Q-11 \\
\hline Nitrate reduction & - & - & + & - \\
\hline DNA G $+C$ content $(\mathrm{mol} \%)$ & 63.6 & 47 & 60.3 & 60 \\
\hline
\end{tabular}

${ }^{*}$ Results from this study. Performed at $30{ }^{\circ} \mathrm{C}$ except for tests on R. antarcticum KCCM $42687^{\mathrm{T}}$ which were performed at $20{ }^{\circ} \mathrm{C}$. 
profile of strain $\mathrm{G} 5^{\mathrm{T}}$ was similar to those of phylogenetically related species, significant differences in the respective proportions of several components, the presence of 11methyl $\mathrm{C}_{18: 1} \omega 7 c$ and the absence of 10 -methyl $\mathrm{C}_{19: 0}$ clearly distinguished the strain from phylogenetically related type strains (Table 2). The major polar lipids were phosphatidylglycerol (PG), monoglycosyldiglyceride (MGDG), glucuronopyranosyldiglyceride (GUDG) and two unidentified glycolipids (GL1 and GL2) (Fig. 3). Among these polar lipids, the presence of MGDG and GUDG appears to be a characteristic of members of the family Hyphomonadaceae (Alain et al., 2008; Kang \& Lee 2009).

Although strain $\mathrm{G}^{\mathrm{T}}$ formed a phylogenetic group with $H$. balneolensis 26III/A02/215 ${ }^{\mathrm{T}}$ with $95.8 \%$ 16S rRNA gene sequence similarity, the $\mathrm{G}+\mathrm{C}$ content of strain $\mathrm{G}^{\mathrm{T}}$ was $63.6 \mathrm{~mol} \%$, which is much higher than that of $H$. balneolensis 26III/A02/215 $5^{\mathrm{T}}$ (47 mol\%) (Table 1, Rosselló-Mora \& Amann, 2001). Based on these results and on its physiological, biochemical and phylogenetic properties, strain $\mathrm{G}^{\mathrm{T}}$ represents a novel species of a novel genus within the family Hyphomonadaceae of the class Alphaproteobacteria, for which the name Litorimonas taeanensis gen. nov., sp. nov. is proposed.

\section{Description of Litorimonas gen. nov.}

Litorimonas (Li.to.ri.mo'nas. L. n. litus -oris beach; L. fem. n. monas monad, unit; N.L. fem. n. Litorimonas beach bacterium).

Cells are Gram-reaction-negative, non-spore-forming, budding, straight to slightly curved rods. Usually nonstalked and motile by means of a polar flagellum; some cells possess one polar stalk (prostheca) and are nonmotile. Oxidase- and catalase-positive. Neither nitrate nor nitrite is reduced. The only isoprenoid quinone detected is ubiquinone-10 (Q-10). The DNA G + C content of the type strain of the type species is $63.6 \mathrm{~mol} \%$ (HPLC). Phylogenetically, the genus Litorimonas is a member of the family Hyphomonadaceae of the class Alphaproteobacteria. The type species is Litorimonas taeanensis.

\section{Description of Litorimonas taeanensis sp. nov.}

Litorimonas taeanensis (tae.an.en'sis. N.L. fem. adj. taeanensis of or belonging to Taean, from where the type strain was isolated).

In addition to the characteristics described for the genus, the species is characterized by the following properties. Cells are $0.4-0.6 \times 1.6-2.0 \mu \mathrm{m}$, strictly aerobic, chemoheterotrophic and moderately halophilic. Colonies on MA are yelloworange, convex and round with entire margins. Growth occurs at $15-40{ }^{\circ} \mathrm{C}$ (optimum $25-30{ }^{\circ} \mathrm{C}$ ), at $\mathrm{pH}$ 6-9 (optimum $\mathrm{pH} 7-8$ ) and in 1-6\% (w/v) $\mathrm{NaCl}$ (optimum 2-3\%). Positive for assimilation of D-glucose but negative for assimilation of L-arabinose, D-mannose, maltose, D-mannitol, malic acid, potassium gluconate, $\mathrm{N}$-acetylglucosamine, capric acid, adipic acid, trisodium citrate and phenylacetic acid (API 20 NE). Positive for alkaline phosphatase, esterase lipase (C8), leucine arylamidase, valine arylamidase, cystine arylamidase,
Table 2. Cellular fatty acid compositions (\%) of strain $\mathrm{G} 5^{\top}$ and type strains of related members of the family Hyphomonadaceae

Taxa: 1, strain $\mathrm{G}^{\mathrm{T}}$; 2, Hellea balneolensis DSM $19091^{\mathrm{T}}$; 3, Robiginitomaculum antarcticum KCCM $42687^{\mathrm{T}}$; 4. Hyphomonas polymorpha DSM $2665^{\mathrm{T}}$. All data from this study. Fatty acids $<1 \%$ in all strains are not shown. tr, Trace amount $(<1 \%) ;-$, not detected. All strains were grown on MA at $30{ }^{\circ} \mathrm{C}$ except for $R$. antarcticum KCCM $42687^{\mathrm{T}}\left(20{ }^{\circ} \mathrm{C}\right)$.

\begin{tabular}{|c|c|c|c|c|}
\hline Fatty acid & 1 & 2 & 3 & 4 \\
\hline \multicolumn{5}{|l|}{ Saturated } \\
\hline $\mathrm{C}_{15: 0}$ & 2.7 & $\operatorname{tr}$ & $\operatorname{tr}$ & 8.9 \\
\hline $\mathrm{C}_{16: 0}$ & 17.7 & 2.6 & $\operatorname{tr}$ & 3.3 \\
\hline $\mathrm{C}_{17: 0}$ & 18.5 & 7.4 & 8.2 & 27.0 \\
\hline $\mathrm{C}_{18: 0}$ & 3.2 & 2.0 & 6.4 & $\operatorname{tr}$ \\
\hline $\mathrm{C}_{19: 0}$ & - & 1.7 & 2.4 & $\operatorname{tr}$ \\
\hline \multicolumn{5}{|l|}{ Unsaturated } \\
\hline $\mathrm{C}_{16: 1} \omega 5 c$ & 2.6 & - & - & $\operatorname{tr}$ \\
\hline $\mathrm{C}_{17: 1} \omega 8 c$ & 6.8 & 2.1 & 8.6 & 17.9 \\
\hline $\mathrm{C}_{17: 1} \omega 6 c$ & 6.5 & 6.2 & 3.8 & 16.5 \\
\hline 11-methyl $\mathrm{C}_{18: 1} \omega 7 c$ & 7.9 & 1.3 & - & 8.4 \\
\hline $\mathrm{C}_{18: 1} \omega 9 c$ & $\operatorname{tr}$ & - & 2.7 & - \\
\hline $\mathrm{C}_{18: 1} \omega 7 c$ & 26.9 & 26.5 & 46.9 & 10.5 \\
\hline 10-methyl $C_{19: 0}$ & - & 21.2 & $\operatorname{tr}$ & - \\
\hline $\mathrm{C}_{20: 1} \omega 9 c$ & & 1.4 & & \\
\hline \multicolumn{5}{|l|}{ Branched } \\
\hline iso- $\mathrm{C}_{19: 0}$ & - & 1.6 & - & - \\
\hline \multicolumn{5}{|l|}{ Hydroxyl } \\
\hline $\mathrm{C}_{11: 1} 3-\mathrm{OH}$ & - & 1.0 & $\operatorname{tr}$ & $\operatorname{tr}$ \\
\hline $\mathrm{C}_{18: 1} 2-\mathrm{OH}$ & - & 9.0 & - & - \\
\hline 10-methyl $\mathrm{C}_{18: 0}$ (TBSA) & - & 5.4 & - & - \\
\hline Unknown ECL 18.814 & - & - & 14.5 & - \\
\hline \multicolumn{5}{|l|}{ Summed features ${ }^{\star}$} \\
\hline 3 & $\operatorname{tr}$ & $\operatorname{tr}$ & 2.8 & - \\
\hline 7 & $\operatorname{tr}$ & 6.6 & $\operatorname{tr}$ & 2.4 \\
\hline
\end{tabular}

${ }^{*}$ Summed features represent groups of two or three fatty acids which could not be separated by GLC with the MIDI system. Summed feature 3 comprises $\mathrm{C}_{16: 1} \omega 7 c$ and/or iso- $\mathrm{C}_{15: 0}$ 2-OH. Summed feature 7 comprises $\mathrm{C}_{19: 0}$ cyclo $\omega 10 c$ and/or $\mathrm{C}_{19: 1} \omega 6 c$ and/or ECL (equivalent chain-length) 18.846 .

trypsin, $\alpha$-chymotrypsin, acid phosphatase and $\alpha$-glucosidase activities but negative for lipase (C14), $\alpha$ - and $\beta$-galactosidase, $\beta$-glucuronidase, $N$-acetyl- $\beta$-glucosaminidase, $\alpha$-mannosidase and $\alpha$-fucosidase activities. Weak enzymic activities are observed for esterase (C4), $\beta$-glucosidase and naphthol-ASB1-phosphohydrolase (API ZYM). Positive for (Biolog GN2) utilization of Tweens 40 and $80, \mathrm{~N}$-acetyl-D-galactosamine, D-arabitol, cellobiose, D-mannitol, D-mannose, pyruvic acid methyl ester, succinic acid mono-methyl ester, formic acid, D-gluconic acid, $\beta$ - and $\gamma$-hydroxybutyric acid, DL-lactic acid, sebacic acid, succinic acid, L-asparagine, glycyl-L-aspartic acid, glycyl-L-glutamic acid, L-ornithine, L-serine, DL-carnitine, $\gamma$-amino butyric acid, inosine, uridine, 2-aminoethanol, glycerol, $\alpha$-DL-glycerol phosphate, $\alpha$-D-glucose-1-phosphate and D-glucose-6-phosphate. Other organic substrates included in Biolog GN2 microplates are not utilized. Resistant 


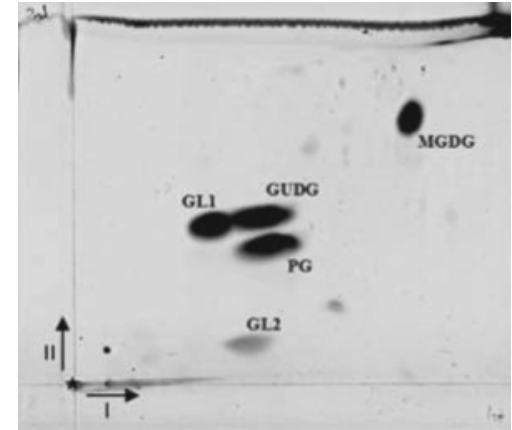

Fig. 3. Thin-layer chromatogram sprayed with molybdatophosphoric acid reagent showing the polar lipid profile of strain $\mathrm{G} 5^{\mathrm{T}}$ following separation by two-dimension TLC. Ascending solvent system: (I) chloroform-methanol-water (65:25:4, v/v/v.); (II) chloroform-acetic acid-methanol-water (80:15:12:4, v/v/v/ v.). For detection of the polar lipids, phosphomolybdic acid (for PG, MGDG, GUDG, GL1 and GL2), ninhydrin (no detection), $\alpha$-naphthol (for MGDG, GUDG, GL1 and GL2) and Dittmer-Lester reagent (for $P G$ ) were applied. $G L$, unidentified glycolipid.

to polymyxin B, streptomycin, gentamicin, kanamycin, novobiocin, oleandomycin, lincomycin, ampicillin, tetracycline, penicillin $G$ and carbenicillin but sensitive to chloramphenicol. PG, MGDG, GUDG and two unidentified glycolipids are the polar lipids detected. The major cellular fatty acids are $\mathrm{C}_{18: 1} \omega 7 c, \mathrm{C}_{17: 0}, \mathrm{C}_{16: 0}, 11$-methyl $\mathrm{C}_{18: 1} \omega 7 c$, $\mathrm{C}_{17: 1} \omega 8 c$ and $\mathrm{C}_{17: 1} \omega 6 c$.

The type strain, G5 ${ }^{\mathrm{T}}$ (=KACC $13701^{\mathrm{T}}=\mathrm{DSM} 22008^{\mathrm{T}}$ ), was isolated from beach sand in Taean, South Korea. The DNA $\mathrm{G}+\mathrm{C}$ content of the type strain is $63.6 \mathrm{~mol} \%$.

\section{Acknowledgements}

These efforts were supported by grants from the Ministry of Science \& Technology, Korea/Korea Science and Engineering Foundation (MOST/KOSEF) to the Environmental Biotechnology National Core Research Center (grant no. R15-2003-012-02002-0) and the 21C Frontier Microbial Genomics and Application Center Program (grant no. MG05-0104-4-0).

\section{References}

Abraham, W.-R., Strömpl, C., Meyer, H., Lindholst, S., Moore, E. R., Christ, R., Vancanneyt, M., Tindall, B. J., Bennasar, A. \& other authors (1999). Phylogeny and polyphasic taxonomy of Caulobacter species. Proposal of Maricaulis gen. nov. with Maricaulis maris (Poindexter) comb. nov. as the type species, and emended description of the genera Brevundimonas and Caulobacter. Int J Syst Bacteriol 49, 1053-1073.

Alain, K., Tindall, B. J., Intertaglia, L., Catala, P. \& Lebaron, P. (2008). Hellea balneolensis gen. nov., sp. nov., a prosthecate alphaproteobacterium from the Mediterranean Sea. Int J Syst Evol Microbiol 58, 2511-2519.

Chun, J., Lee, J. H., Jung, Y., Kim, M., Kim, S., Kim, B. K. \& Lim, Y. W. (2007). EzTaxon: a web-based tool for the identification of prokaryotes based on $16 \mathrm{~S}$ ribosomal RNA gene sequences. Int J Syst Evol Microbiol 57, 2259-2261.

Felsenstein, J. (2002). PHYLIP (phylogeny inference package), version 3.6a, Seattle:Department of Genetics, University of Washington, Seattle, WA,USA.
Jeon, C. O., Park, W., Ghiorse, W. C. \& Madsen, E. L. (2004), Polaromonas naphthalenivorans sp. nov., a naphthalene-degrading bacterium from naphthalene-contaminated sediment. Int J Syst Evol Microbiol 54, 93-97.

Kahng, H.-Y., Chung, B. S., Lee, D.-H., Jung, J.-S., Park, J. H. \& Jeon, C. O. (2009). Cellulophaga tyrosinoxydans sp. nov., a tyrosinase-producing bacterium isolated from seawater. Int J Syst Evol Microbiol 59, 654-657.

Kang, H. S. \& Lee, S. D. (2009). Ponticaulis koreensis gen. nov., sp. nov., a new member of the family Hyphomonadaceae isolated from seawater. Int J Syst Evol Microbiol 59, 2951-2955.

Kim, J. M., Le, N. T., Chung, B. S., Park, J. H., Bae, J.-W., Madsen, E. L. \& Jeon, C. O. (2008). Influence of soil components on the biodegradation of benzene, toluene, ethylbenzene, and $o^{-}, \mathrm{m}^{-}$, and $p$-xylenes by the newly isolated bacterium Pseudoxanthomonas spadix BD-a59. Appl Environ Microbiol 74, 7313-7320.

Kim, J. M., Lee, S. H., Jung, J. Y. \& Jeon, C. O. (2010). Marinobacterium lutimaris sp. nov., isolated from a tidal flat. Int $J$ Syst Evol Microbiol 60, 1828-1831.

Komagata, K. \& Suzuki, K. (1987). Lipid and cell-wall analysis in bacterial systematics. Methods Microbiol 19, 161-207.

Lai, Q., Yuan, J. \& Shao, Z. (2009). Maribaculum marinum gen. nov., sp. nov., isolated from deep seawater. Int J Syst Evol Microbiol 59, 3083-3087.

Lanyi, B. (1987). Classical and rapid identification methods for medically important bacteria. Methods Microbiol 19, 1-67.

Lee, K. B., Liu, C. T., Anzai, Y., Kim, H., Aono, T. \& Oyaizu, H. (2005). The hierarchical system of the 'Alphaproteobacteria': description of Hyphomonadaceae fam. nov., Xanthobacteraceae fam. nov. and Erythrobacteraceae fam. nov. Int J Syst Evol Microbiol 55, 1907-1919.

Lee, K., Lee, H.-K., Choi, T.-H. \& Cho, J.-C. (2007). Robiginitomaculum antarcticum gen. nov., sp. nov., a member of the family Hyphomonadaceae, from Antarctic seawater. Int J Syst Evol Microbiol 57, 2595-2599.

Lu,S., Park, M., Ro, H.-S., Lee, D.S., Park, W. \& Jeon, C. O.(2006). Analysis of microbial communities using culture-dependent and culture-independent approaches in an anaerobic/aerobic SBR reactor. J Microbiol 44, 155-161.

Minnikin, D. E., Patel, P. V., Alshamaony, L. \& Goodfellow, M. (1977). Polar lipid composition in the classification of Nocardia and related bacteria. Int J Syst Bacteriol 27, 104-117.

Rosselló-Mora, R. \& Amann, R. (2001). The species concept for prokaryotes. FEMS Microbiol Rev 25, 39-67.

Smibert, R. M. \& Krieg, N. R. (1994). Phenotypic characterization. In Methods for General and Molecular Bacteriology, pp. 607-654. Edited by P. Gerhardt. Washington, D.C.: American Society for Microbiology.

Strömpl, C., Hold, G. L., Lünsdorf, H., Graham, J., Gallacher, S., Abraham, W.-R., Moore, E. R. B. \& Timmis, K. N. (2003). Oceanicaulis alexandrii gen. nov., sp. nov., a novel stalked bacterium isolated from a culture of the dinoflagellate Alexandrium tamarense (Lebour) Balech. Int J Syst Evol Microbiol 53, 1901-1906.

Tamaoka, J. \& Komagata, K. (1984). Determination of DNA base composition by reversed-phase high-performance liquid chromatography. FEMS Microbiol Lett 25, 125-128.

Thompson, J. D., Higgins, D. G. \& Gibson, T. J. (1994). CLUSTAL W: improving the sensitivity of progressive multiple sequence alignment through sequence weighting, position-specific gap penalties and weight matrix choice. Nucleic Acids Res 22, 4673-4680.

Weiner, R. M., Devine, R. A., Powell, D. M., Dagasan, L. \& Moore, R. L. (1985). Hyphomonas oceanitis sp. nov., Hyphomonas hirschiana sp. nov., and Hyphomonas jannaschiana sp. nov. Int J Syst Bacteriol 35, 237-243.

Weiner, R. M., Melick, M., O’Neill, K. \& Quintero, E. (2000). Hyphomonas adhaerens sp. nov., Hyphomonas johnsonii sp. nov. and Hyphomonas rosenbergii sp. nov., marine budding and prosthecate bacteria. Int J Syst Evol Microbiol 50, 459-469. 